\title{
Nitric oxide synthase, Calcitonin Gene-Related Peptide and inflammatory mechanisms are involved in GTN induced neuronal activation
}

\author{
R Ramachandran, K Bhatt, I Jansen-Olesen, J Olesen ${ }^{*}$ \\ From The European Headache and Migraine Trust International Congress \\ London, UK. 20-23 September 2012
}

\section{Introduction and objective}

Infusion of glyceryl trinitrate (GTN), a nitric oxide (NO) donor in awake freely moving rats closely mimics a universally accepted human model of migraine and responds to sumatriptan treatment $[1,2]$. Here we analyse the effect of nitric oxide synthase (NOS) and calcitonin gene-related peptide (CGRP) systems on the GTN induced neuronal activation in this model.

\section{Methods}

The femoral vein was catheterized and rat allowed recovering for ten days before infusion of GTN $(4 \mu \mathrm{g} / \mathrm{kg} / \mathrm{min}$, for $20 \mathrm{~min}$, i.v.). Immunohistochemistry was used to measure Fos, nNOS and CGRP protein expression. Western blot was done to re-confirm the nNOS expression. Olcegepant $(1 \mathrm{mg} / \mathrm{kg})$ for 3 mins was given both as a pre-treatment and post treatment to analyse its effect on Fos activation. The response to pre-treatment with L-NAME $(40 \mathrm{mg} / \mathrm{kg})$ and NK-1 antagonist, L-733060 $(1 \mathrm{mg} / \mathrm{kg})$ was also measured at the activation level.

\section{Conclusion}

The present study indicates that inhibition of CGRP, NOS and inflammatory systems all block GTN induced neuronal activation. These findings also predict that pre-treatment with olcegepant may be a better option than post-treatment to study inhibitory effect on GTN migraine models.

Published: 21 February 2013

\section{References}

1. Thomsen $L L$, Olesen J: Nitric oxide in primary headaches. Curr. Opin. Neurol 2001, 14:315-321.

2. Ramachandran R, Bhatt DK, Ploug KB, Olesen J, Jansen-Olesen I,

Hay-Schmidt A, Gupta S: A naturalistic GTN infusion migraine model in the rat. Cephalalgia 2011.

doi:10.1186/1129-2377-14-S1-P217

Cite this article as: Ramachandran et al:: Nitric oxide synthase, Calcitonin Gene-Related Peptide and inflammatory mechanisms are involved in GTN induced neuronal activation. The Journal of Headache and Pain 2013 14(Suppl 1):P217.

\section{Results}

GTN treated rats showed a significant increase of nNOS and CGRP in dura and CGRP in trigeminal nucleus caudalis (TNC). Upregulation of the nociceptive marker Fos was observed in TNC at 2 and 4 hrs after the infusion. The activation at $4 \mathrm{hrs}$ was inhibited by pre-treatment with olcegepant. However, post treatment with olcegepant could not inhibit this activation. Pre-treatment with L-NAME and L-733060 also significantly inhibited the GTN induced Fos expression.

Submit your manuscript to a SpringerOpen ${ }^{\circ}$ journal and benefit from:

- Convenient online submission

- Rigorous peer review

- Immediate publication on acceptance

- Open access: articles freely available online

- High visibility within the field

- Retaining the copyright to your article

Submit your next manuscript at $>$ springeropen.com 